\title{
Tingkat sosial ekonomi tidak berhubungan dengan kurang energi kronis (KEK) pada ibu hamil
}

Sosioeconomic status did not associate with chronic energy deficiency (CED) in pregnant women

Indriany ${ }^{1}$, Siti Helmyati ${ }^{2}$, Bunga Astria $P^{3}$

\begin{abstract}
Background: Chronic energy deficiency (CED) has been experienced in almost all countries, especially in developing countries such as Bangladesh, India, Indonesia, Myanmar, Nepal, Srilanka, and Thailand. There are several cause factors of CED, one of them is socioeconomic level such as education, employment, knowledge, and family income.

Objectives: To analyze the relationship between socioeconomic level and CED in Sedayu Subdistrict, Bantul, Yogyakarta.

Methods: This was an observational study with cross sectional design. Population were all pregnant women in Sedayu Subdistrict. Samples were selected by using total sampling methods with total sample 201 pregnant women. Data were analyzed by using univariate analysis (descriptive), bivariat (chi-square), and multivariat (multiple logistic regression).

Results: There were no significant relationship between maternal education ( $p=0.167, R P=1.55,95 \% \mathrm{Cl}: 0.84$ 2.87), maternal employment ( $p=0.360, R P=1.33,95 \% \mathrm{Cl}: 0.72-2.44)$, maternal knowledge $(p=0.892, R P=0.96$, 95\% Cl:0.49-1.85) and CED in pregnant women at Sedayu Subdistrict. However, there was significant relationship between family income with CED in pregnant woman ( $p=0.004, R P=2.73,95 \% C l: 1.31-5.68$ ). Multivariat analysis showed that there was significant relationship between family income with CED in pregnant women $\left(R^{2}=0.08, O R=3.22,95 \% \mathrm{Cl}: 1.28-8.11\right)$. Low family income had a 3.22 times higher chance to incidence of CED in pregnant women.

Conclusions: Sosioeconomic status such as education, employment, knowledge did not associate with CED in pregnant women. However, there was significant association in family income of pregnant women with CED and non CED.
\end{abstract}

KEYWORDS: chronic energy deficiency, maternal education, employment, maternal knowledge, family income

\begin{abstract}
ABSTRAK
Latar belakang: Kurang energi kronis (KEK) dialami oleh hampir semua negara khususnya di negara-negara berkembang seperti Bangladesh, India, Indonesia, Myanmar, Nepal, Srilanka, dan Thailand. Salah satu faktor yang dapat mempengaruhi KEK pada ibu hamil adalah tingkat sosial ekonomi seperti pendidikan ibu, pengetahuan ibu, pekerjaan ibu, dan pendapatan keluarga.

Tujuan: Untuk mengetahui hubungan antara tingkat sosial ekonomi dengan kejadian KEK pada ibu hamil di Kecamatan Sedayu, Bantul, Yogyakarta.

Metode: Jenis penelitian ini adalah observasional dengan desain cross sectional. Populasi penelitian adalah seluruh ibu hamil yang ada di Kecamatan Sedayu. Pemilihan sampel menggunakan total sampling dengan jumlah sampel 201 ibu hamil. Data dianalisis dengan menggunakan analisis univariat (deskriptif), bivariat (chi-square), dan multivariat (regresi logistik).
\end{abstract}

\footnotetext{
1 Pasca Sarjana IImu Kesehatan Masyarakat Minat Gizi dan Kesehatan Fakultas Kedokteran Universitas Gadjah Mada, JI. Farmako Sekip Utara Yogyakarta 55281, e-mail: indriany.ugm@gmail.com

2 Program Studi Gizi dan Kesehatan, Fakultas Kedokteran Universitas Gadjah Mada, Jl. Farmako, Sekip Utara, Yogyakarta 55281, e-mail: siti_helmyati@yahoo.com

${ }_{3}^{3}$ Program Studi S1 IImu Gizi, STIKES Alma Ata Yogyakarta, Jl. Ring Road Barat Daya No 1, Yogyakarta, Yogyakarta 55183, e-mail: pshanti.bunga@gmail.com
} 
Hasil: Hasil analisis menunjukkan tidak ada hubungan antara pendidikan ibu ( $p=0,17, R P=1,55,95 \% \mathrm{Cl}: 0,84-$ 2,87), pekerjaan ibu ( $p=0,36, R P=1,33,95 \% \mathrm{Cl}: 0,72-2,44)$, dan pengetahuan ibu ( $p=0,83, R P=0,96,95 \%$ Cl:0,49-1,85) dengan kejadian KEK pada Ibu hamil. Namun demikian, terdapat hubungan yang signifikan antara pendapatan keluarga dengan KEK ibu hamil ( $p=0,004, R P=2,73,95 \% \mathrm{Cl}: 1,31-5,68)$. Analisis multivariat menunjukkan bahwa pendapatan keluarga mempunyai hubungan dengan kejadian KEK pada ibu hamil $\left(R^{2}=0,08, O R=3,22,95 \% \mathrm{Cl}: 1,28-8,11\right)$, pendapatan keluarga yang rendah memiliki peluang 3,22 kali untuk mengalami kejadian KEK pada ibu hamil.

Kesimpulan: Tingkat sosial ekonomi seperti pendidikan, pekerjaan, pengetahuan ibu tidak berhubungan dengan KEK pada ibu hamil, namun pendapatan keluarga memiliki hubungan yang bermakna secara signifikan antara ibu hamil KEK dan tidak KEK.

KATA KUNCI: kurang energi kronis, pendidikan, pekerjaan, pengetahuan, pendapatan keluarga

\section{PENDAHULUAN}

Kehamilan merupakan permulaan suatu kehidupan baru pada periode pertumbuhan. Kondisi kesehatan di masa lampau sekaligus keadaan kesehatan ibu saat ini merupakan landasan suatu kehidupan baru (1). Ibu hamil adalah salah satu kelompok yang paling rawan terhadap masalah gizi. Masalah gizi yang dialami ibu hamil sebelum atau selama kehamilan dapat mempengaruhi pertumbuhan janin yang sedang dikandung. Masalah gizi yang dialami ibu hamil seperti kekurangan energi kronis (KEK), anemia, dan kurang yodium (2). KEK merupakan keadaan status gizi seseorang yang buruk disebabkan kurangnya konsumsi pangan sumber energi yang mengandung zat gizi makro yang berlangsung lama atau menahun (3). KEK pada kehamilan telah banyak diketahui memberikan dampak negatif pada ibu hamil dan janin yang dikandungnya. Salah satu dampak negatif yang sangat menonjol adalah risiko kematian ibu saat melahirkan dan bayi lahir dengan berat badan rendah (4).

Prevalensi wanita yang mengalami KEK adalah $15-47 \%$ di hampir semua negara khususnya negara-negara berkembang (5). Berdasarkan data riset kesehatan dasar (Riskesdas) tahun 2013, prevalensi ibu hamil yang mengalami KEK sebesar 24,2\% (6). Menurut data Profil Kesehatan Provinsi DIY tahun 2011, prevalensi ibu hamil KEK sebesar $14,4 \%$, angka ini meningkat dibandingkan tahun 2010 sebesar 14,41\% (7). Profil Gizi Kabupaten Bantul tahun 2012 menunjukkan bahwa prevalensi ibu hamil KEK sebesar 13,8\%, sementara di Kecamatan Sedayu (I dan II) adalah 11,4\% (8).
Pendidikan merupakan salah satu ukuran yang digunakan dalam status sosial ekonomi. Pada perempuan, semakin tinggi tingkat pendidikan, semakin rendah angka kematian bayi dan ibu (9). Perempuan yang bekerja di luar rumah dan mendapatkan penghasilan akan meningkatkan pengaruhnya dalam alokasi pendapatan keluarga. Pendapatan yang berasal dari perempuan berkorelasi erat dengan semakin membaiknya derajat kesehatan keluarga (10). Tingkat pendapatan mempunyai hubungan yang nyata positif dengan status gizi ibu hamil. Hal ini berarti semakin tinggi tingkat pendapatan, maka status gizi ibu hamil semakin baik (11). Kekurangan gizi bisa terjadi akibat ketidaktahuan. Seseorang yang memiliki kemudahan akses pangan bisa saja memilih makanan yang kurang atau tidak bergizi karena ketidaktahuannya. Tingkat pengetahuan gizi seseorang akan berpengaruh terhadap sikap dan perilaku dalam pemilihan makanan. Oleh karena itu, diperlukan pengetahuan ibu yang baik mengenai gizi dan kesehatan agar kebutuhan gizi selama hamil bisa terpenuhi (2). Adapun tujuan dari penelitian ini adalah untuk melihat hubungan antara tingkat sosial ekonomi (pendidikan, pekerjaan, pengetahuan, dan pendapatan) dengan kejadian KEK pada ibu hamil di Kecamatan Sedayu, Bantul, Yogyakarta.

\section{BAHAN DAN METODE}

Jenis penelitian ini adalah observasional analitik dengan rancangan cross sectional. Penelitian dilaksanakan di Kecamatan Sedayu Kabupaten Bantul pada periode bulan Maret hingga 
Mei 2014. Penelitian ini merupakan bagian dari penelitian yang berjudul "Status Gizi lbu Hamil dan Baduta di Kecamatan Sedayu Kabupaten Bantul D.I Yogyakarta" yang dilaksanakan oleh Alma Ata Center For Healthy Life and Food (ACHEAF) Yogyakarta. Subjek penelitian adalah seluruh ibu hamil di Kecamatan Sedayu Kabupaten Bantul yang telah sesuai dengan kriteria inklusi dan eksklusi. Adapun kriteria inklusi adalah ibu hamil tinggal/berdomisili di Kecamatan Sedayu Kabupaten Bantul, bersedia mentaati prosedur penelitian dan menandatangani formulir persetujuan, ibu hamil dengan kehamilan tunggal (bukan janin kembar). Kriteria eksklusi dalam penelitian ini adalah ibu hamil yang tidak mempunyai tangan (cacat), menderita penyakit penyerta yang berat, seperti gangguan kesadaran/ koma/penurunan kesadaran.

Teknik pengambilan sampel pada penelitian ini menggunakan teknik total sampling. Peneliti mengambil sampel dari seluruh ibu hamil yang berdomisili di Kecamatan Sedayu Kabupaten Bantul. Jumlah sampel dalam penelitian ini adalah 201 ibu hamil. Variabel terikat pada penelitian ini adalah KEK, sedangkan variabel bebas yaitu pekerjaan ibu, pendidikan ibu, tingkat pengetahuan ibu, dan pendapatan keluarga. Variabel luar yang juga akan diteliti adalah umur ibu, paritas, pengeluaran pangan, pemanfaatan pelayanan antenal care (ANC), umur kehamilan, dan ketersediaan pangan. Instrumen pada penelitian ini adalah kuesioner, data dokumentasi berupa daftar ibu hamil (dari posyandu), buku KIA (kesehatan ibu dan anak), dan pita LILA (lingkar lengan atas). Kuesioner penelitian berupa software Commcare ODK yang telah di-install ke dalam handphone android version dengan pemilik hak paten adalah Alma Ata Center for Healthy Life and Food (ACHEAF) Yogyakarta. Daftar pertanyaan dalam kuesioner dan hasil pengukuran, di-input ke dalam software Commcare ODK tersebut, sehingga dalam pelaksanaan wawancara terhadap responden cukup menggunakan handphone android version.

Data dasar responden diambil dengan cara melakukan wawancara langsung kepada responden berupa umur ibu, pekerjaan ibu, tingkat pendidikan, pengetahuan, pendapatan keluarga, pengeluaran pangan, pemanfaatan pelayanan kesehatan (ANC), paritas, umur kehamilan, dan ketersediaan pangan. Daftar ibu hamil diperoleh dari Puskesmas Sedayu I dan Sedayu II serta dari kader posyandu di masingmasing posyandu.

Uji validitas untuk kuesioner pengetahuan, dilakukan pada 42 ibu hamil di Kecamatan Sedayu pada bulan Juli 2013 sebelum penelitian berlangsung yang memenuhi kriteria inklusi dengan menggunakan SPSS 20. Uji validitas menggunakan analisis corrected item-total correlation, dari 20 item pertanyaan kuesioner. Setelah dianalisi diperoleh 12 item pertanyaan yang valid untuk kuesioner pengetahuan. Penelitian ini telah mendapat persetujuan dari Komisi Etik Penelitian Kedokteran dan Kesehatan Fakultas Kedokteran Universitas Gadjah Mada nomor Ref: KE/ FK/382/EC tahun 2014.

\section{HASIL}

\section{Karakteristik subjek penelitian}

Jumlah subjek pada penelitian ini adalah 201 ibu hamil yang tersebar di Kecamatan Sedayu I dan Sedayu II. Berdasarkan Tabel 1, ibu hamil yang mengalami KEK jauh lebih sedikit dibandingkan dengan ibu hamil yang tidak KEK, dengan persentase KEK sebesar $17,91 \%$. Proporsi terbesar ibu hamil berusia antara 20-35 tahun dengan persentase sebesar $82,09 \%$ dan untuk paritas, sebagian besar ibu hamil memiliki $\leq 1$ anak dengan proporsi sebesar $86,57 \%$.

Sebagian besar ibu hamil di Kecamatan Sedayu memiliki tingkat pendidikan yang tinggi dengan persentase $75,62 \%$, dibandingkan ibu hamil yang berpendidikan rendah. Selain itu, tingkat pengetahuan ibu hamil sebagian besar kurang dengan persentase sebesar $73,63 \%$. Jika melihat distribusi pekerjaan ibu hamil pada Tabel 1, ibu hamil yang tidak bekerja lebih banyak dengan proporsi sebesar $54,23 \%$ dibandingkan dengan yang bekerja, pada kelompok yang bekerja terlihat bahwa jenis pekerjaan yang paling banyak adalah sebagai karyawan swasta sebesar $17,41 \%$.

Berdasarkan tabel distribusi tingkat pendapatan yang menggunakan nilai median didapatkan bahwa sebagian ibu hamil memiliki pendapatan keluarga rendah dengan besar proporsi yaitu 56,22\%. 
Tabel 1. Distribusi karakteristik responden

\begin{tabular}{|c|c|c|}
\hline Variabel & $\mathbf{n}$ & $\%$ \\
\hline \multicolumn{3}{|l|}{ Status gizi } \\
\hline KEK & 36 & 17,91 \\
\hline Tidak KEK & 165 & 82,09 \\
\hline \multicolumn{3}{|l|}{ Usia ibu } \\
\hline$<20$ tahun dan $>35$ tahun & 36 & 17,91 \\
\hline 20-35 tahun & 165 & 82,09 \\
\hline \multicolumn{3}{|l|}{ Paritas } \\
\hline$>1$ & 27 & 13,43 \\
\hline$\leq 1$ & 174 & 86,57 \\
\hline \multicolumn{3}{|l|}{ Tingkat pendidikan ibu } \\
\hline Rendah & 49 & 24,28 \\
\hline Tinggi & 152 & 75,62 \\
\hline \multicolumn{3}{|l|}{ Jenis pendidikan } \\
\hline Tidak tamat SD/SMP/SMA & 3 & 1,49 \\
\hline Tamat SD/sederajat/Paket A & 9 & 4,48 \\
\hline Tamat SMP/sederajat/Paket B & 37 & 18,41 \\
\hline Tamat SMA/sederajat/Paket C & 107 & 53,23 \\
\hline Perguruan tinggi & 45 & 22,39 \\
\hline \multicolumn{3}{|l|}{ Tingkat pengetahuan ibu } \\
\hline Kurang & 148 & 73,63 \\
\hline Cukup & 53 & 26,37 \\
\hline \multicolumn{3}{|l|}{ Jenis pekerjaan } \\
\hline Buruh/buruh tani & 8 & 3,98 \\
\hline Karyawan swasta & 35 & 17,41 \\
\hline Pegawai negeri/TNI/Polri & 8 & 3,98 \\
\hline Wiraswasta & 18 & 8,96 \\
\hline Guru honorer & 8 & 3,98 \\
\hline Penjahit & 6 & 2,99 \\
\hline Tidak bekerja & 109 & 54,23 \\
\hline Dosen tetap/tidak tetap & 2 & 1,00 \\
\hline Pedagang & 3 & 1,49 \\
\hline Pegawai kontrak RS & 1 & 0,50 \\
\hline Pengrajin & 2 & 1,00 \\
\hline Pembantu rumah tangga & 1 & 0,50 \\
\hline \multicolumn{3}{|l|}{ Pekerjaan ibu } \\
\hline Tidak bekerja & 109 & 54,23 \\
\hline Bekerja & 92 & 45,77 \\
\hline \multicolumn{3}{|l|}{ Tingkat pendapatan keluarga } \\
\hline Rendah & 113 & 56,22 \\
\hline Tinggi & 88 & 43,78 \\
\hline \multicolumn{3}{|l|}{ Tingkat pengeluaran pangan } \\
\hline Rendah & 101 & 50,25 \\
\hline Tinggi & 100 & 49,75 \\
\hline \multicolumn{3}{|l|}{ Pemanfaatan pelayanan ANC } \\
\hline Tidak memanfaatkan & 21 & 10,45 \\
\hline Memanfaatkan & 180 & 89,55 \\
\hline \multicolumn{3}{|l|}{ Umur kehamilan } \\
\hline Trimester 1 dan 2 & 61 & 30,35 \\
\hline Trimester 3 & 140 & 69,65 \\
\hline \multicolumn{3}{|l|}{ Ketersediaan pangan } \\
\hline Rawan kelaparan tingkat berat & 6 & 2,99 \\
\hline $\begin{array}{l}\text { Rawan kelaparan tingkat } \\
\text { sedang }\end{array}$ & 7 & 3,48 \\
\hline Rawan tanpa kelaparan & 20 & 9,95 \\
\hline Terjamin & 168 & 83,58 \\
\hline
\end{tabular}

Sementara itu, tingkat pengeluaran berdasarkan nilai median juga dapat dikatakan bahwa sebagian besar ibu hamil memiliki pengeluaran pangan rendah dengan proporsi sebesar $50,25 \%$. Hanya sebagian kecil ibu hamil yang tidak memanfaatkan pelayanan ANC dengan persentase $10,45 \%$ dan sebagian besar ibu hamil memanfaatkan pelayanan ANC dengan persentase sebesar $89,55 \%$. Untuk distribusi umur kehamilan sebagian besar umur kehamilan ibu adalah trimester 3 dengan proporsi sebesar $69,65 \%$. Ketersediaan pangan keluarga ibu hamil sebagian besar terjamin dengan proporsi sebesar $83,58 \%$.

\section{Hubungan karakteristik subjek dengan risiko KEK}

Hasil analisis bivariat karakteristik subjek penelitian dapat dilihat pada Tabel 2. Sebagian besar variabel memiliki nilai $p>0,05$ yang artinya tidak ada perbedaan karakteristik antara ibu hamil yang KEK maupun tidak KEK. Ibu hamil yang KEK sebagian besar berusia antara 20-35 tahun dengan persentase $18,79 \%$. Ibu hamil KEK proporsi paritasnya lebih banyak yang memiliki anak $\leq 1$ yaitu sebesar $18,97 \%$. Ibu hamil KEK sebagian besar tidak memanfaatkan pelayanan ANC dengan proporsi sebesar $23,81 \%$. Proporsi terbesar ibu hamil KEK terdapat pada ibu hamil yang memiliki tingkat pengeluaran pangan rendah sebesar $18,81 \%$. Jika dilihat dari persentase pengeluaran pangan dibandingkan dengan pengeluaran total menunjukkan hasil $p=0,685$ yang berarti bahwa tidak terdapat perbedaan secara signifikan antara kelompok $\operatorname{KEK}(52,05 \% \pm 15,03)$ dan tidak KEK $(53,21 \% \pm 17,44)$. Sementara itu, ibu hamil yang KEK proporsi terbesar terjadi pada trimester 1 dan 2 sebesar $24,59 \%$. Proporsi terbesar untuk ibu hamil KEK juga terdapat pada keluarga yang ketersediaan pangan tidak terjamin dengan proporsi sebesar $33,33 \%$.

\section{Hubungan tingkat pendidikan, pekerjaan, tingkat pengetahuan, tingkat pendapatan keluarga dengan kejadian KEK pada ibu hamil}

Berdasarkan hasil analisis bivariat antara hubungan tingkat pendidikan ibu, pekerjaan ibu, tingkat pengetahuan ibu, dan tingkat pendapatan keluarga dengan kejadian KEK pada ibu hamil dapat 
Tabel 2. Distribusi karakteristik ibu hamil

\begin{tabular}{|c|c|c|c|c|c|c|}
\hline \multirow{3}{*}{ Karakteristik } & \multicolumn{4}{|c|}{ Status gizi ibu hamil } & \multirow{3}{*}{$\begin{array}{c}\text { RP } \\
(95 \% \mathrm{Cl})\end{array}$} & \multirow{3}{*}{$\mathbf{p}$} \\
\hline & \multicolumn{2}{|c|}{ KEK } & \multicolumn{2}{|c|}{ Tidak KEK } & & \\
\hline & $\mathbf{n}$ & $\%$ & 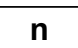 & $\%$ & & \\
\hline \multicolumn{7}{|l|}{ Usia ibu } \\
\hline$<20$ tahun dan $>35$ tahun & 5 & 13,89 & 31 & 86,11 & 0,74 & 0,49 \\
\hline 20-35 tahun & 31 & 18,79 & 134 & 81,21 & $(0,31-1,77)$ & \\
\hline \multicolumn{7}{|l|}{ Paritas } \\
\hline$>1$ anak & 3 & 11,11 & 24 & 88,89 & 0,59 & 0,32 \\
\hline$\leq 1$ anak & 33 & 18,97 & 141 & 81,03 & $(0,19-1,78)$ & \\
\hline Pemanfaatan pelayanan ANC & 5 & 23,81 & 16 & 76,19 & 1,38 & \\
\hline Tidak memanfaatkan & 31 & 17,22 & 149 & 82,78 & $(0,60-3,17)$ & 0,46 \\
\hline Memanfaatkan & & & & & & \\
\hline \multicolumn{7}{|l|}{ Tingkat pengeluaran pangan } \\
\hline Rendah & 19 & 18,81 & 82 & 81,19 & 1,11 & 0,74 \\
\hline Tinggi & 17 & 17,00 & 83 & 83,00 & $(0,61-2,00)$ & \\
\hline Persentase pengeluaran pangan dibandingkan & \multirow{2}{*}{\multicolumn{2}{|c|}{$52,05 \pm 15,03$}} & \multirow{2}{*}{\multicolumn{2}{|c|}{$53,21 \pm 17,44$}} & & \\
\hline $\begin{array}{l}\text { dengan total pengeluaran rumah tangga per } \\
\text { bulan }(\%)(\text { mean } \pm S D)^{\dagger}\end{array}$ & & & & & $(-6,77-0,46)$ & 0,685 \\
\hline \multicolumn{7}{|l|}{ Umur kehamilan } \\
\hline Trimester 1 dan 2 & 15 & 24,59 & 46 & 75,41 & 1,64 & 0,10 \\
\hline Trimester 3 & 21 & 15,00 & 119 & 85,00 & $(0,91-2,96)$ & \\
\hline \multicolumn{7}{|l|}{ Ketersediaan pangan } \\
\hline Rawan pangan & 11 & 33,33 & 22 & 66,67 & 2,24 & $0,01^{*}$ \\
\hline Terjamin & 25 & 14,88 & 143 & 85,12 & $(1,23-4,09)$ & \\
\hline
\end{tabular}

* Signifikan $(p<0,05)$

${ }^{\dagger}$ Analisis menggunakan uji t-test independent

dilihat pada Tabel 3. Ibu hamil KEK sebagian besar berpendidikan rendah dengan proporsi sebesar $24,49 \%$. Hasil uji statistik menunjukkan nilai $p>0,05$ yang berarti tidak ada hubungan yang signifikan antara pendidikan ibu dengan kejadian KEK pada ibu hamil dengan perbandingan prevalensi 1,55 , $95 \% \mathrm{Cl}(0,84-2,87)$.
Untuk pekerjaan ibu, sebagian besar ibu hamil KEK tidak bekerja dengan proporsi sebesar 20,18\%. Dari hasil uji statistik didapatkan nilai $p>0,05$ yang berarti tidak ada hubungan antara pekerjaan ibu dengan kejadian KEK pada ibu hamil dengan perbandingan prevalensi sebesar $1,33,95 \% \mathrm{Cl}$ $(0,72-2,44)$.

Tabel 3. Analisis bivariat tingkat sosial ekonomi dengan kejadian KEK pada ibu hamil

\begin{tabular}{|c|c|c|c|c|c|c|}
\hline \multirow{3}{*}{ Variabel } & \multicolumn{4}{|c|}{ Status gizi ibu hamil } & \multirow{3}{*}{$\begin{array}{c}\text { RP } \\
(95 \% \mathrm{Cl})\end{array}$} & \multirow{3}{*}{$\mathbf{p}$} \\
\hline & \multicolumn{2}{|c|}{ KEK } & \multicolumn{2}{|c|}{ Tidak KEK } & & \\
\hline & $n$ & $\%$ & $\mathbf{n}$ & $\%$ & & \\
\hline \multicolumn{7}{|l|}{ Tingkat pendidikan ibu } \\
\hline Rendah & 12 & 24,49 & 37 & 75,51 & 1,55 & 0,167 \\
\hline Tinggi & 24 & 15,79 & 128 & 84,21 & $(0,84-2,87)$ & \\
\hline \multicolumn{7}{|l|}{ Pekerjaan ibu } \\
\hline Tidak bekerja & 22 & 20,18 & 87 & 79,82 & 1,33 & 0,360 \\
\hline Bekerja & 14 & 15,22 & 78 & 84,78 & $(0,72-2,44)$ & \\
\hline \multicolumn{7}{|c|}{ Tingkat pengetahuan ibu } \\
\hline Kurang & 26 & 17,69 & 121 & 82,31 & 0,96 & 0,892 \\
\hline Cukup & 10 & 18,52 & 44 & 81,48 & $(0,49-1,85)$ & \\
\hline \multicolumn{7}{|c|}{ Tingkat pendapatan keluarga } \\
\hline Rendah & 28 & 24,78 & 85 & 75,22 & 2,73 & $0,004^{*}$ \\
\hline Tinggi & 8 & 9,09 & 80 & 90,91 & $(1,31-5,68)$ & \\
\hline
\end{tabular}

* Signifikan $(p<0,05)$ 
Pada tingkat pengetahuan ibu, proporsi terbesar ibu hamil KEK terdapat pada ibu hamil yang memiliki pengetahuan cukup dengan besar proporsi yaitu $18,52 \%$. Dari hasil uji statistik didapatkan nilai $p>0,05$ yang berarti tidak ada hubungan antara tingkat pengetahuan dengan kejadian KEK pada ibu hamil dengan perbedaan prevalensi sebesar $0,96,95 \% \mathrm{Cl}(0,49-1,85)$.

Jika dilihat dari tingkat pendapatan keluarga, sebagian besar ibu hamil KEK memiliki tingkat pendapatan keluarga rendah dan dari hasil uji statistik didapatkan nilai $p<0,05$ yang berarti ada hubungan antara pendapatan keluarga dengan kejadian KEK pada ibu hamil dengan perbandingan prevalensi sebesar 2,73 kali lebih besar, $95 \% \mathrm{Cl}(1,31-5,68)$. Dengan demikian, dapat dikatakan bahwa ibu hamil dengan pendapatan keluarga rendah mempunyai peluang sebesar 2,73 kali untuk mengalami KEK dibandingkan dengan ibu hamil yang memiliki pendapatan tinggi. Hasil analisis bivariat untuk variabel pendidikan ibu, pekerjaan ibu, pengetahuan ibu, dan pendapatan keluarga dapat dilihat pada Tabel 3.

\section{Analisis stratifikasi}

Analisis stratifikasi dilakukan untuk mengetahui peran variabel confounding dan atau effect modifier pada hubungan pendapatan keluarga dengan kejadian KEK pada ibu hamil. Variabel yang distratifikasi adalah ketersediaan pangan dan umur kehamilan, analisis stratifikasi ini menggunakan uji Mantel Haenzel.

Berdasarkan Tabel 4 dapat diketahui bahwa selisih rasio prevalensi Mantel Haenzel (RP-MH) dan crude RP variabel ketersediaan pangan dan umur kehamilan masing-masing sebesar $-11,72 \%$ dan $0,073 \%$. Selisih nilai RP-MH dan crude RP masing-masing variabel kurang dari $20 \%$, sehingga variabel ketersediaan pangan dan umur kehamilan bukan confounding factor pada hubungan antara pendapatan keluarga dengan kejadian KEK pada ibu hamil. Pada variabel ketersediaan pangan tidak terdapat perbedaan nilai RP antarstrata, sehingga dapat disimpulkan bahwa ketersediaan pangan juga bukan merupakan effect modifier.

Pada variabel umur kehamilan didapatkan bahwa ada perbedaan nilai RP antarstrata sehingga dapat dikatakan bahwa umur kehamilan merupakan effect modifier terhadap hubungan pendapatan keluarga dengan kejadian KEK pada ibu hamil. Dengan demikian, pada ibu hamil yang memiliki pendapatan rendah pada trimester 1 dan 2 memiliki peluang sebesar 11,12 kali lebih besar untuk mengalami KEK dibandingkan dengan ibu hamil pada trimester 3. Di samping itu, jika ibu hamil tersebut memiliki pendapatan keluarga tinggi pada umur kehamilan trimester 1 dan 2 juga akan memiliki

Tabel 4. Analisis stratifikasi variabel ketersediaan pangan dan umur kehamilan pada hubungan pendapatan keluarga dengan kejadian KEK pada ibu hamil

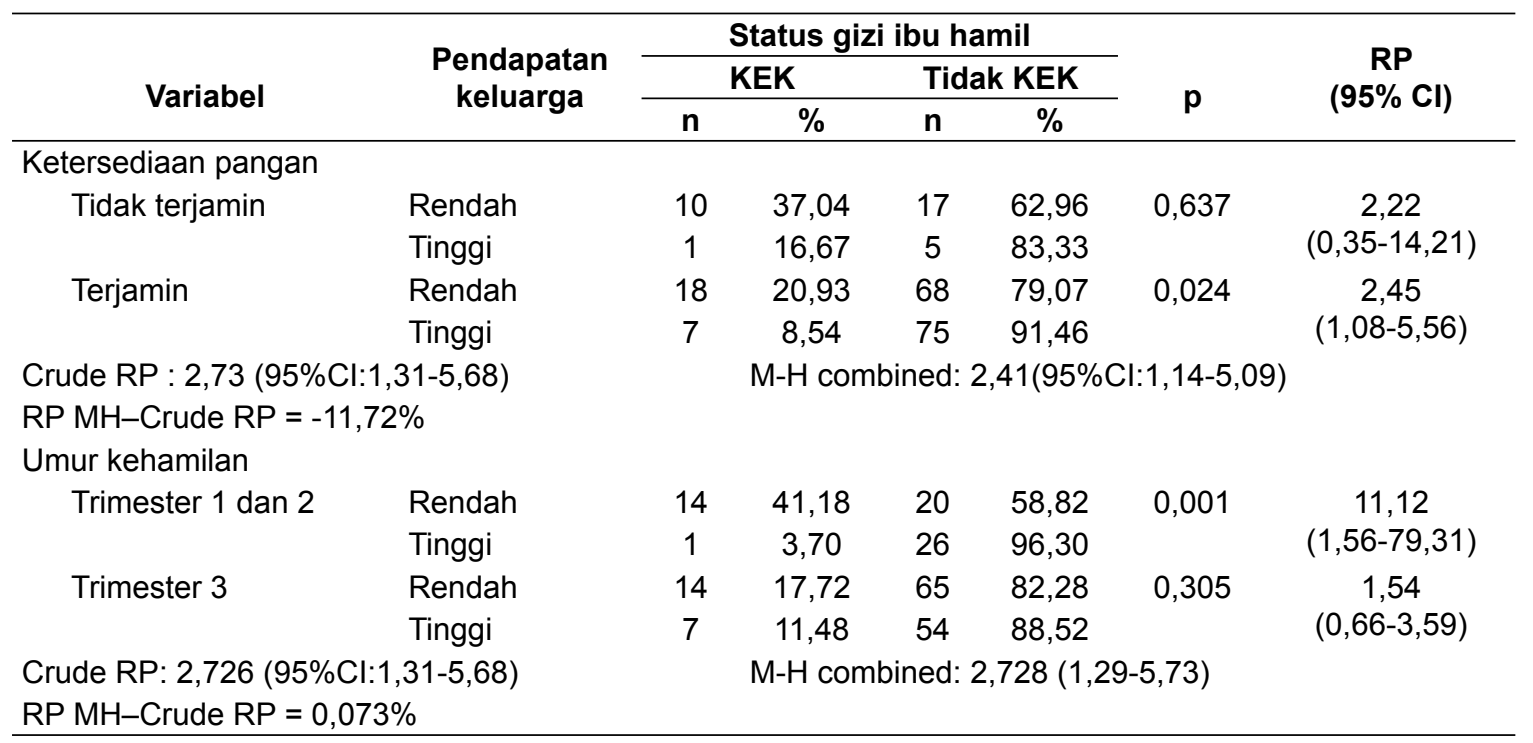


risiko yang sama untuk mengalami KEK, dengan kata lain pendapatan keluarga akan memiliki risiko untuk mengalami KEK pada trimester 1 dan 2.

\section{Analisis multivariat}

Analisis multivariat menggunakan uji regresi logistik dengan melakukan permodelan yang bertujuan untuk melihat pengaruh variabel luar terhadap pendidikan ibu, pekerjaan ibu, tingkat pengetahuan, dan tingkat pendapatan dengan kejadian KEK pada ibu hamil. Variabel luar yang dimasukan ke dalam analisis multivariat ini adalah yang memiliki nilai $p<0,25$ (12) yaitu variabel umur kehamilan dan ketersediaan pangan.

Berdasarkan analisis multivariat, model 1 menunjukkan pengaruh variabel bebas tanpa memasukan variabel luar dengan nilai $R^{2}$ diperoleh sebesar 0,05 . Hal ini berarti variabel pendidikan ibu, pekerjaan ibu, pengetahuan ibu, dan pendapatan keluarga dapat memprediksi kejadian KEK pada ibu hamil sebesar $5 \%$. Model 2 menunjukkan besarnya pengaruh variabel bebas terhadap kejadian KEK setelah memasukan variabel umur kehamilan pada analisis dengan menghasilkan nilai $R^{2}(0,07)$ yang artinya pendidikan ibu, pekerjaan ibu, pengetahuan ibu, dan pendapatan keluarga setelah dikontrol oleh umur kehamilan dapat memprediksi kejadian KEK pada ibu hamil sebesar $7 \%$.

Model 3 pada analisis regresi logistik tersebut menunjukkan pengaruh variabel bebas setelah memasukan variabel ketersediaan pangan menghasilkan nilai $R^{2}$ sebesar 0,07 yang berarti variabel pendidikan ibu, pekerjaan ibu, tingkat pengetahuan ibu, dan pendapatan keluarga setelah dikontrol oleh variabel ketersediaan pangan dapat memprediksi kejadian KEK pada ibu hamil sebesar $7 \%$. Model 4 pada analisis regresi logistik menunjukkan besarnya pengaruh variabel bebas setelah memasukan secara bersamaan semua variabel luar yaitu umur kehamilan dan ketersediaan pangan dan menghasilkan nilai $R^{2}$ sebesar 0,08 yang berarti variabel pendidikan ibu, pekerjaan ibu, tingkat pengetahuan ibu, dan pendapatan keluarga setelah dikontrol oleh umur kehamilan dan ketersediaan pangan dapat memprediksi kejadian KEK sebesar 8\%.
Berdasarkan hasil uji multivariat dengan melakukan permodelan di atas, yang diambil sebagai model yang terbaik adalah model 4 karena memiliki nilai $R^{2}$ yang besar dibandingkan dengan model 1, 2, dan 3. Hal ini berarti bahwa pada model ini adalah paling besar memprediksi kejadian KEK pada ibu hamil. Pada model 4 terlihat bahwa variabel pendapatan keluarga mempunyai pengaruh paling besar terhadap kejadian KEK dengan nilai $\mathrm{OR}=3,22$ setelah dikontrol oleh variabel luar yaitu umur kehamilan dan ketersediaan pangan.

\section{BAHASAN}

Pada tabel analisis multivariat (Tabel 5) menunjukkan tidak terdapat hubungan antara pendidikan dan KEK pada ibu hamil. Hasil ini tidak sesuai dengan hipotesis awal yang mengatakan bahwa terdapat hubungan antara pendidikan ibu dengan kejadian KEK pada ibu hamil. Pada penelitian ini, sebagian besar ibu hamil memiliki pendidikan rendah dan tidak KEK. Hasil yang tidak signifikan bisa disebabkan informasi gizi tidak selalu didapatkan dari pendidikan formal, tetapi bisa didapatkan dari mana saja seperti puskesmas, bidan, sesama ibu hamil, ataupun dari media massa.

Hasil penelitian ini serupa dengan penelitian yang menunjukkan hasil bahwa tidak terdapat hubungan yang signifikan antara pendidikan ibu dengan kejadian KEK pada ibu hamil $(13,14)$. Seseorang dengan pendidikan rendah belum tentu kurang mampu menyusun makanan yang memenuhi persyaratan gizi dibandingkan dengan yang berpendidikan tinggi. Sekalipun berpendidikan rendah, jika orang tersebut rajin mendengarkan atau melihat informasi mengenai gizi dapat mempengaruhi kemampuannya untuk menyusun makanan yang bergizi. Sebaliknya, seseorang yang berpendidikan tinggi belum tentu bisa menyusun makan yang bergizi dengan baik karena aktivitas yang tinggi dan pola hidup yang tidak teratur (13). Hasil penelitian ini tidak sejalan dengan penelitian di Kota Manado tahun 2011 dan India Selatan tahun 2006 hingga 2007 yang menunjukkan hasil bahwa ada hubungan yang signifikan antara pendidikan ibu 
Tabel 5. Tabel analisis regresi logistik

\begin{tabular}{|c|c|c|c|c|}
\hline Variabel & $\begin{array}{c}\text { Model } 1 \\
\text { OR } \\
(95 \% \mathrm{Cl})\end{array}$ & $\begin{array}{c}\text { Model } 2 \\
\text { OR } \\
(95 \% \mathrm{Cl})\end{array}$ & $\begin{array}{c}\text { Model } 3 \\
\text { OR } \\
(95 \% \mathrm{Cl})\end{array}$ & $\begin{array}{c}\text { Model } 4 \\
\text { OR } \\
(95 \% \mathrm{Cl})\end{array}$ \\
\hline \multicolumn{5}{|l|}{ Pendidikan ibu } \\
\hline Rendah & 1,17 & 1,25 & 0,75 & 0,80 \\
\hline Tinggi & $(0,49-2,73)$ & $(0,53-2,97)$ & $(0,27-2,05)$ & $(0,29-2,23)$ \\
\hline \multicolumn{5}{|l|}{ Pekerjaan ibu } \\
\hline Tidak bekerja & 1,12 & 1,04 & 1,04 & 0,97 \\
\hline Bekerja & $(0,52-2,40)$ & $(0,48-2,26)$ & $(0,48-2,27)$ & $(0,44-2,14)$ \\
\hline \multicolumn{5}{|l|}{ Pengetahuan ibu } \\
\hline Kurang & 0,81 & 0,68 & 0,81 & 0,67 \\
\hline Cukup & $(0,35-1,89)$ & $(0,28-1,64)$ & $(0,34-1,90)$ & $(0,27-1,63)$ \\
\hline \multicolumn{5}{|l|}{ Pendapatan keluarga } \\
\hline Rendah & 3,12 & 3,26 & 3,10 & 3,22 \\
\hline Tinggi & $(1,26-7,72)$ & $(1,29-8,18)$ & $(1,25-7,72)$ & $(1,28-8,11)$ \\
\hline \multicolumn{5}{|l|}{ Umur kehamilan } \\
\hline Trimester 1 dan 2 & - & 2,08 & & 2,13 \\
\hline Trimester 3 & & $(0,94-4,59)$ & - & $(0,95-4,77)$ \\
\hline \multicolumn{5}{|l|}{ Ketersediaan pangan } \\
\hline Tidak terjamin & - & - & 2,62 & 2,69 \\
\hline Terjamin & & & $(0,94-7,27)$ & $(0,96-7,54)$ \\
\hline $\mathbf{R}^{2}$ & 0,05 & 0,07 & 0,07 & 0,08 \\
\hline $\mathbf{N}$ & 201 & 201 & 201 & 201 \\
\hline
\end{tabular}

dengan kejadian KEK pada ibu hamil $(15,16)$.

Berdasarkan analisis multivariat menunjukkan hasil yang tidak signifikan antara hubungan pekerjaan ibu dengan KEK pada ibu hamil (Tabel 5). Hasil penelitian ini sejalan dengan penelitian yang dilakukan di Kabupaten Gowa yang juga mengatakan bahwa tidak ada hubungan antara pekerjaan ibu dengan kejadian $\operatorname{KEK}(13,15)$. Pada penelitian ini yang dimaksud pekerjaan adalah kegiatan untuk menghasilkan uang yang akan mempengaruhi pendapatan keluarga. Dengan kata lain, hasil yang tidak signifikan pada penelitian ini bisa disebabkan faktor pekerjaan tidak secara langsung mempengaruhi status gizi. Ibu hamil bekerja yang memiliki penghasilan di bawah rata-rata bisa memiliki status gizi yang tidak baik. Berdasarkan analisis multivariat model 4 yang dipilih terlihat bahwa faktor pekerjaan memberikan hasil yang tidak signifikan, sedangkan pada pendapatan keluarga memberikan hasil yang signifikan dan pengaruh yang paling besar terhadap kejadian KEK pada ibu hamil.

Pada suatu penelitian menunjukkan hasil bahwa terdapat perbedaan yang nyata yaitu prevalensi risiko KEK yang lebih tinggi pada ibu hamil yang bekerja sebagai petani/buruh $(24,1 \%)$, pekerja tidak menentu $(25,7 \%)$, dan tidak bekerja $(31,9 \%)(17)$. Hal ini juga sebelumnya sudah dijelaskan dalam penelitian dimana proporsi ibu hamil yang mengalami risiko KEK lebih banyak pada ibu hamil yang tidak bekerja (18). Wanita yang berperan sebagai ibu rumah tangga memiliki tingkat kesehatan yang lebih rendah daripada wanita yang memiliki pekerjaan serta rutinitas di luar rumah seperti wanita karir dan pekerja swasta aktif (15). Hasil yang tidak sejalan dengan penelitian ini ditunjukan pada penelitian yang dilakukan di Kota Semarang tahun 2011 yang menjelaskan bahwa ada hubungan yang signifikan antara pekerjaan ibu dengan kejadian KEK pada ibu hamil (14).

Hasil analisis multivariat untuk pengetahuan ibu menunjukkan bahwa tidak ada hubungan antara pengetahuan dengan KEK pada ibu hamil $(p>0,05)$ (Tabel 5). Hasil penelitian ini sejalan dengan penelitian yang dilakukan di Kabupaten Jepara yang menunjukkan bahwa tidak ada hubungan antara pengetahuan ibu dengan status gizi ibu hamil dan KEK pada ibu hamil $(19,20)$. Hasil yang tidak signifikan pada penelitian ini bisa disebabkan orang yang berpengetahuan belum tentu menerapkan dalam 
kehidupan sehari-hari, seperti pengetahuan tentang gizi dan kesehatan kehamilan seperti yang dijelaskan pada suatu penelitian yang dilakukan di Semarang (21). Pengetahuan dasar mengenai gizi yang cukup tanpa diikuti oleh sikap, keterampilan, dan kemauan untuk bertindak tidak dapat membawa perubahan perbaikan gizi yang baik (22).

Pada penelitian di Kabupaten Jepara tahun 2013 juga menjelaskan bahwa pengetahuan yang kurang tidak selalu diikuti oleh perilaku yang buruk. Adanya responden yang pengetahuannya kurang tetapi berstatus gizi baik bisa disebabkan daya beli yang tinggi terhadap makanan yang mempunyai nilai gizi tinggi meskipun pengetahuannya kurang (20). Hasil penelitian ini berbeda dengan penelitian yang dilakukan di Kabupaten Simalungun tahun 2008. Pada penelitian tersebut, pengetahuan mempengaruhi kejadian KEK pada ibu hamil (23). Hasil berbeda dengan penelitian ini juga dijelaskan pada suatu penelitian di Wilayah Kerja Puskesmas Cibolang yang mengatakan bahwa ada hubungan yang signifikan antara pengetahuan ibu dengan kejadian KEK pada ibu hamil (24).

Hasil analisis multivariat untuk tingkat pendapatan menunjukkan hasil yang signifikan (Tabel 5). Hal ini berarti bahwa ada hubungan antara pendapatan keluarga dengan kejadian KEK pada ibu hamil. Pendapatan rumah tangga mempengaruhi status gizi ibu hamil yang berarti semakin tinggi tingkat pendapatan, maka ada kecenderungan dapat meningkatkan status gizi. Hasil penelitian ini sejalan dengan penelitian yang dilakukan di India Selatan tahun 2006 hingga 2007, India dan Pekanbaru tahun 2014 yang menunjukkan bahwa terdapat hubungan yang signifikan antara pendapatan keluarga per bulan dengan kejadian KEK pada ibu hamil dan wanita usia subur $(16,25,26)$.

Tingkat pendapatan menentukan pola makanan yang dibeli. Semakin tinggi pendapatan, semakin bertambah pula pengeluaran untuk belanja makanan. Hal ini menyangkut pemenuhan kebutuhan dalam keluarga terutama pemenuhan kebutuhan akan makanan yang memiliki nilai gizi dengan jumlah yang cukup. Dengan demikian, pendapatan merupakan faktor yang menentukan kualitas dan kuantitas makanan (15). Pendapatan keluarga berhubungan positif, yang berarti bahwa semakin tinggi pendapatan keluarga maka semakin baik status kesehatan yang dilihat berdasarkan angka indeks massa tubuh (IMT) dan LILA (25). Pada analisis multivariat terlihat jelas bahwa variabel pendapatan keluarga yang memberikan pengaruh paling besar di antara variabel lain terhadap kejadian KEK pada ibu hamil $(\mathrm{OR}=3,22$, $95 \% \mathrm{Cl}: 1,28-8,11)$. Pendapatan keluarga memiliki nilai $\mathrm{OR}=3,22$ yang berarti bahwa ibu hamil dengan pendapatan keluarga yang rendah akan meningkatkan risiko kejadian KEK pada ibu hamil sebesar 3,22 kali dibandingkan dengan ibu hamil yang memiliki pendapatan keluarga yang tinggi.

\section{KESIMPULAN DAN SARAN}

Tidak ada hubungan yang signifikan antara pendidikan ibu, pekerjaan ibu, dan pengetahuan ibu dengan kejadian KEK pada ibu hamil. Namun demikian, terdapat hubungan yang signifikan antara pendapatan keluarga dengan kejadian KEK pada ibu hamil di Kecamatan Sedayu, Kabupaten Bantul, Provinsi DIY. Untuk meningkatkan pendapatan keluarga diharapkan bisa memberikan keterampilan kepada ibu hamil dengan cara membuat pelatihan dalam membuat kerajinan dari barang-barang bekas, merajut tas dan dompet mengingat ada beberapa pabrik pembuat benda rajutan di sekitar Sedayu.

\section{RUJUKAN}

1. Bobak M, Lowdermilk D, Jensen M. Buku ajar keperawatan maternitas. Jakarta: Penerbit Buku Kedokteran EGC; 2004.

2. Mawaddah N, Hardinsyah. Pengetahuan, sikap, dan praktek gizi serta tingkat konsumsi ibu hamil di Kelurahan Kramat Jati dan Kelurahan Ragunan Propinsi DKI Jakarta. JGIZIPANGAN. 2008;3(1):30-42.

3. Rahmaniar A, Taslim N a, Baharuddin B. Faktorfaktor yang berhubungan dengan kekurangan energi kronis pada ibu hamil di Tampa Padang Kabupaten Mamuju, Sulawesi Barat. Media Gizi Masy Indones. 2013;2:98-103. 
4. Departemen Kesehatan RI. Program gizi makro. Jakarta: Direktorat Jenderal Bina Kesehatan Masyarakat; 2002.

5. World Health Organization (WHO). Adolescent nutrition: a review of the situation in selected South-East Asian Countries. New Delhi: WHO; 2006.

6. Dinas Kesehatan Republik Indonesia. Riset kesehatan dasar 2013. Jakarta: Badan Litbangkes $\mathrm{Rl} ; 2013$.

7. Dinas Kesehatan Provinsi DIY. Profil kesehatan Provinsi DI Yogyakarta. Yogyakarta: Dinas Kesehatan Provinsi DIY; 2011.

8. Dinas Kesehatan Kabupaten Bantul. Profil gizi Kabupaten Bantul. Bantul: Dinas Kesehatan Kabupaten Bantul; 2012.

9. Timmreck C. Epidemiologi suatu pengantar pekerjaan dan pendidikan sebagai karakteristik orang. Jakarta: Penerbit Buku Kedokteran EGC; 2005.

10. Khomsan A. Pangan dan gizi untuk kesehatan. Jakarta: PT. Raja Grafindo Persada; 2005.

11. Hermawan W. Faktor-faktor yang berpengaruh terhadap resiko kurang energi kronis (KEK) pada ibu hamil di Kecamatan Cimalaka Kabupaten Sumedang. Institut Pertanian Bogor; 2006.

12. Dahlan S. Analisis multivariat regresi logistik. Jakarta: Epidemiologi Indonesia; 2012.

13. Ausa S, Jafar N, Indriasari R. Hubungan pola makan dan status sosial ekonomi dengan kejadian KEK pada ibu hamil di Kabupaten Gowa. Universitas Hasanuddin; 2013.

14. Bunga Widita Kartikasari, Mifbakhuddin DNM. Hubungan pendidikan, paritas, dan pekerjaan ibu dengan status gizi ibu hamil trimester III di Puskesmas Bangetayu Kecamatan Genuk Kota Semarang tahun 2011. J Kebidanan. 2011;1(1).

15. Najoan J, Manampiring A. Hubungan tingkat kurang sosial ekonomi dengan kurang energi konik pada ibu hamil di Kelurahan Kombos Barat Kecamatan Singkil Kota Manado. Universitas Sam Ratulangi. Manado; 2011 p. 1-44.

16. Subasinghe AK, Walker KZ, Evans RG, Srikanth V, Arabshahi S, Kartik K, et al. Association between farming and chronic energy deficiency in rural South India. PLoS One. 2014;9(1): e87423.
17. Sandjaja. Risiko kurang energi kronis (KEK) pada ibu hamil di Indonesia. Gizi Indones. 2009;32(2):128-38.

18. Mulyaningrum S. Faktor-faktor yang berhubungan dengan risiko kurang energi kronis (KEK) pada ibu hamil di Provinsi DKI Jakarta (analisis data Riskesdas 2007). Universitas Indonesia; 2009.

19. Widayanti T, Meikawati W, Astuti R. Faktorfaktor yang berhubungan dengan kekurangan energi kronis (KEK) pada ibu hamil di Desa Welahan Kecamatan Welahan Kabupaten Jepara. Universitas Muhammadiyah Semarang; 2012.

20. Susanti A. Budaya pantang makan, status ekonomi dan pengetahuan zat gizi ibu hamil pada ibu hamil trimester III dengan status gizi. JIKK. 2013;4(1):1-9.

21. Ginting $H$. Hubungan tingkat konsumsi energi dan protein dengan status gizi ibu hamil di Kelurahan Purwoyoso Kecamatan Ngaliyan. Universitas Muhammadiyah Semarang; 2010.

22. Soekirman. IImu gizi dan aplikasinya untuk keluarga dan masyarakat. Jakarta: Direktorat Jendral Pendidikan Tinggi, Departemen Pendidikan Nasional; 2000.

23. Simarmata M. Hubungan pola asupan, ketersediaan pangan, pengetahuan gizi dan status kesehatan dengan kejadian KEK pada ibu hamil di Kabupaten Simulungun. Universitas Sumatera Utara; 2008.

24. Sadli M, Banurea T. Hubungan pengetahuan, penghasilan keluarga dan budaya dengan kejadian kekurangan energi kronis pada ibu hamil. J Kesehat. 2011;2:3-7.

25. Bose K, Bisai S, Das P, Dikshit S, Pradhan S. Relationship of income with anthropometric indicators of chronic energy deficiency among adult female slum dwellers of Midnapore Town. J Hum Ecol. 2007;22(2):171-6.

26. Wati L, Ernalia Y, Haslinda L. Hubungan pengetahuan mengenai gizi, pendapatan keluarga dan infestasi soil transmitted helminths dengan kurang energi kronik (KEK) pada ibu hamil di daerah pesisir Sungai Siak Pekanbaru. J Online Mhs. 2012;1(2) 